\title{
Psychological Capital, Organizational Commitment and Job Performance: A Case in Vietnam
}

\author{
Ha Minh NGUYEN ${ }^{1}$, Trung Thanh NGO²
}

Received: February 24, 2020 Revised: March 08, 2020 Accepted: April 03, 2020

\begin{abstract}
The purpose of this study is to explore the relationship between employee's psychological capital, organizational commitment and job performance in Vietnam. In this study, psychological capital and overall organizational commitment are considered as two secondorder constructs. Psychological capital includes four different components: self-efficacy, optimism, hope and resiliency. Organizational commitment comprises three different components: affective commitment, continuance commitment and normative commitment. The study uses the combination of quantitative research method and qualitative research method. Qualitative research method (based on the experts' opinions) is used to design the official questionnaire, while relationship between concepts is estimated by quantitative research method, which is inclusive of the methods of descriptive statistics, Cronbach's Alpha, EFA, CFA and CB-SEM. The survey is conducted in two ways: face-to-face and via email. Data are collected from 848 employees across provinces and cities in Vietnam. The findings show that psychological capital and job performance have a positive relationship, organizational commitment has positive influence on job performance, and psychological capital is also related to organizational commitment. All relationship between psychological capital, organizational commitment and job performance of employee are statistically significant. In addition, organizational commitment also plays the mediating role in the positive relationship between psychological capital and employee's performance.
\end{abstract}

Keywords: Psychological Capital, Organizational Commitment, Job Performance.

JEL Classification Code: M12, M54, D91.

\section{Introduction}

In recent years, psychological capital has received a lot of attention in organization's psychology. Psychological capital has been considered as the newest resource that can become an advantage in organization's competition activity. It lies beyond social capital and human capital to achieve competitive advantage through investment or development in "who you are" (Luthans, Luthans, \& Luthans, 2004). Psychological capital is used for improving employee's job performance (Luthans \& Youssef, 2004). Employee's job performance has been considered as a set of behaviors

\footnotetext{
${ }^{1}$ First Author. Associate Professor, Ho Chi Minh City Open University, Vietnam. Email: ha.nm@ou.edu.vn

${ }^{2}$ Corresponding Author. Lecturer, Ho Chi Minh City Open University, Vietnam [Postal Address: No. 35-37, Ho Hao Hon Street, Co Giang Ward, District 1, Ho Chi Minh City, 710000, Vietnam] Email: trung.nt@ou.edu.vn

(c) Copyright: The Author(s)

This is an Open Access article distributed under the terms of the Creative Commons Attribution Non-Commercial License (https://creativecommons.org/licenses/by-nc/4.0/) which permits unrestricted non-commercial use, distribution, and reproduction in any medium, provided the original work is properly cited.
}

that have the relation with the goals of the organization he works under (Murphy \& Kroeker, 1988). In addition, in psychological theory, employee's behaviors are led by their attitudes. Organizational commitment is an employee's specific attitude towards his job.

Organizational commitment is an attraction with the nature, which is attitude towards an organization, and the goal of this attitude is toward the organization in general, not a characteristic or role of a particular job (Hulin, 1991). The relationship between psychological capital and job performance has been shown by theories and previous empirical studies (Nolzen, 2018; Newman, Ucbasaran, Zhu, \& Hirst, 2014; Nguyen \& Nguyen, 2012; Luthans \& Jensen, 2005; Larson \& Luthans, 2006; Newman et al., 2014; and Aminikhah, Khaneghah, \& Naghdian, 2016) also confirmed that psychological capital is a significantly related to organizational commitment. On the contrary, results of previous empirical studies regarding the effect of organizational commitment on job performance are not consistent (Wright \& Bonett, 2002).

This study aims to explore the relationship between employee's psychological capital, organizational commitment, 
and job performance in the context of Vietnam, and the mediating role of organizational commitment in the relationship between psychological capital and job performance. Based on the results, the study makes recommendations assisting managers increasing employee's job performance accordingly.

\section{Literature Review}

\subsection{Psychological Capital}

Psychological capital is a second-order construct, the human nature and a positive psychological state in the development of individuals (Avey, Luthans, \& Jensen, 2009). Psychological capital comprises four different components: self-efficacy, optimism, hope and resiliency. These positive resources are demonstrated to be state-like by Luthans, Youssef, and Avolio (2015). Hence, they are easy to be developed and improved through training programs, on-the-job activities, and highly focused and short "microinterventions" (Luthans, Avey, Avolio, \& Peterson, 2010).

\subsection{Organizational Commitment}

The commitment to an organization is defined as employee's loyalty to that organization, willingness to strive on behalf of the organization and desire to be the organization's member longer (Bateman \& Strasser, 1984). Organizational commitment is a psychological state that links an individual to the organization based on a strong adherence to the organization's goals and values (Allen \& Meyer, 1990). It is also an individual's psychological engagement to that organization, by which the attachment to organization, acceptance and transformation of the organization's values and goals into employee's and behavioral effort to support organization are recognized (Judge \& Kammeyer-Mueller, 2012). Organizational commitment is a psychological relation between employee and his organization that helps to constraint the employee's ability to quit current job (Nguyen \& Tu, 2020).

Organizational commitment comprises three different components (Meyer \& Allen, 1991), including affective commitment, continuance commitment, and normative commitment. Emotional engagement to the organization, awareness on related cost if leaving and obligation to keep working are clearly explained, respectively.

\subsection{Job Performance}

Employee's job performance is defined in relation to working goals of the organization where employee belongs to, and it exists in the form of human behavior. Job performance is conceptualized as observable behaviors by which employees perform their jobs in terms of organization's goals (Campbell, McHenry, \& Wise, 1990), or is employee's behaviors involve in actual work which can be observed at that time (Campbell, McCloy, Oppler, \& Sager, 1993), or is a set of all work-related behaviors of employees expected by their organization (Moorhead \& Griffin, 2008). Job performance of organization's members plays an important role to increase organization's competitive capability (Yang \& Kim, 2018).

\subsection{Relationship between Psychological Capital, Organizational Commitment and Job Perfor- mance.}

The positive effect of psychological capital on job performance has been suggested by the theory of psychological capital and previous empirical studies. Psychological capital is used to improve job performance (Luthans \& Youssef, 2004). It is a psychological resource that was able to exhort employee's development and job performance at the individual-level (Luthans, Avolio, Walumbwa, \& Li, 2005). Individuals with high level of psychological capital have more resources to achieve their goals, then are more productive at work (Luthans, Avolio, Avey, \& Norman, 2007; Luthans, Norman, Avolio, \& Avey, 2008). All components of psychological capital are selfefficacy, optimism, hope and resilience that have a positive impact on job performance. Individuals with more selfefficacy have a stronger belief in their ability to control results and more success in solving difficult challenges than individuals with less self-efficacy (Bandura, 1997). Hence, Bandura (1997) calls employees who have their selfefficacy the good performers. Peterson and Byron (2008) say that employees with more hope are more productive at work. Optimistic employees have a positive correlation with their performance (Corr \& Gray, 1996). There is a positive relationship between resiliency and employee performance (Youssef \& Luthans, 2007).

$\mathbf{H}_{1}$ : Psychological capital has positive influence on job performance.

With self-efficacy, employee believes that difficulties and obstacles will help them to be well-trained and mature (Luthans et al., 2015). When employee is assigned works suitable to his job needs or he himself is supported to set work goals easily, he will be satisfied and has more willingness to work at his organization for a long-term period. In other words, this employee will have feeling to be attached to the organization. Hope pushes employee to have a future vision, job itself and job's success. Hopeful employee feels positive about his job (Farran, Herth, \& Popovich, 1995) and wants to keep working at the organization. Results of empirical studies of Larson and Luthans (2006) and Youssef and Luthans 
(2007) show that there is a relationship between hope and employee's organizational commitment. Kluemper, Little, and DeGroot (2009) state that optimists tend to believe in positive results in future. This optimistic interpretation style helps them to objectively perceive temporary events caused by external factors (Youssef \& Luthans, 2007). It also helps optimists to have positive feelings to both their life and their job that they are assigned. Apart from optimism, resiliency to challenges in the workplace also makes the employee feel positively while evaluating his job. He will feel satisfied his job's needs and gain a working commitment attitude at the organization in a long-term period. Results of empirical studies (Luthans \& Jensen, 2005; Larson \& Luthans, 2006; Newman et al., 2014; Aminikhah et al., 2016) show that there is a positive effect of psychological capital on employee's organizational commitment.

$\mathbf{H}_{2}$ : Psychological capital has positive influence on organizational commitment.

Employees who commit to the organization focus more on getting the organization's goals than specific tasks (Hulin, 1991). They try to accomplish and achieve high performance in tasks assigned with the belief that what they do will contribute to the accomplishment of the organization's goals and values. Previous studies have used the metaanalysis method (Wright \& Bonett, 2002; Jaramillo, Mulki, \& Marshall, 2005; Riketta, 2002) and empirical studies of Meyer, Paunonen, Gellatly, Goffin, and Jackson (1989) and Shore and Martin (1989) also show that organizational commitment has a positive impact on job performance. This study proposes hypothesis as follows:

$\mathbf{H}_{3}$ : Organizational commitment has positive influence on job performance.

In addition, based on the above hypotheses about the positive relationship between psychological capital and employee's organizational commitment, and between employee's organizational commitment and employee's job performance, the study proposes a hypothesis about the mediating role of organizational commitment in the relationship between psychological capital and employee's job performance as follows:

$\mathbf{H}_{4}$ : Psychological capital has positive influence on job performance through the mediating role of organizational commitment.

\section{Research Methodology}

\subsection{Research Model}

The research model is described below (see Figure 1): In this study, four hypotheses are proposed as follows:

Hypothesis $1\left(\mathbf{H}_{1}\right)$ : Psychological capital has positive influence on job performance.

Hypothesis $2\left(\mathbf{H}_{2}\right)$ : Psychological capital has positive influence on organizational commitment.

Hypothesis $3\left(\mathbf{H}_{3}\right)$ : Organizational commitment has positive influence on job performance.

Hypothesis $4\left(\mathbf{H}_{4}\right)$ : Psychological capital has positive influence on job performance through the mediating role of organizational commitment.

\subsection{Measurement Scale}

In order to correspond with the research context in Vietnam, a pre-designed questionnaire is revised via qualitative research (based on experts'opinions). Ten experts, including researchers in human resources management, business leaders and employees with at least five years of working experience, join in the discussions to check the suitability of the questionnaire's content and evaluate the usage of the five-point Likert scale in measuring response levels. They are also able to edit and add item (if any).

Psychological capital scale: With the purpose of evaluating employee's psychological capital level, this study refers to the PCQ-24 psychological capital questionnaire edition, which has been very popular in a lot of previous

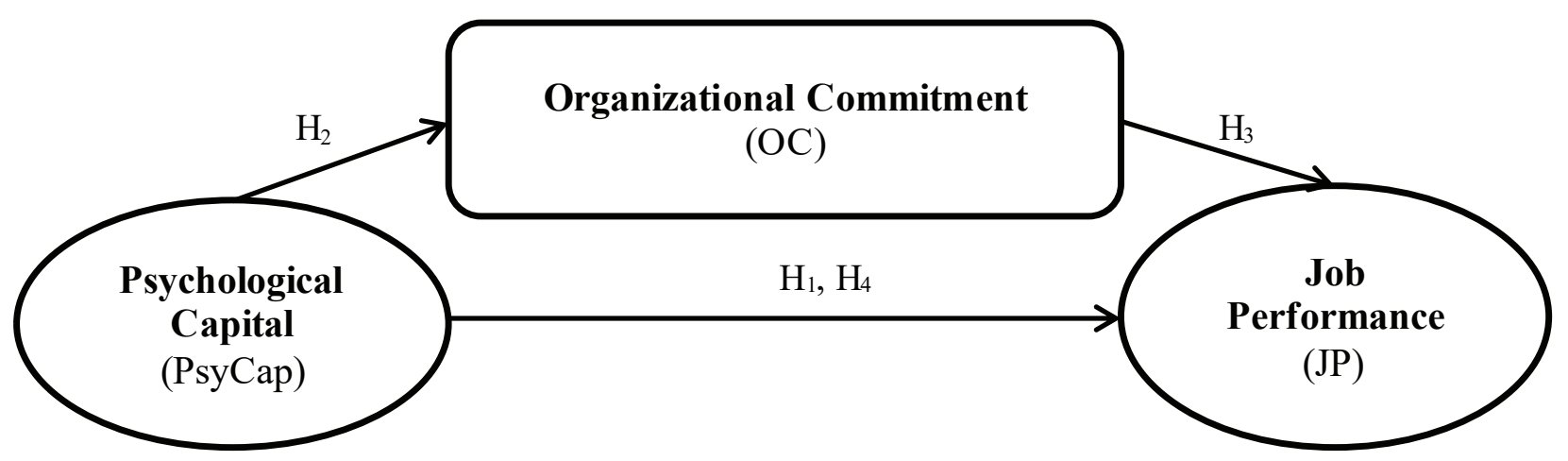

Figure 1: Research model 
studies. Through discussion with experts, pre-design questionnaire is edited and appended. Specifically, the optimism scale has two existing items revised, the resiliency scale has one items altered and there are two new items added for each scale including hope, resiliency, and optimism. Therefore, the numbers of each component is six, eight, eight, eight, respectively, and the final psychological capital scale included 30 items.

Organizational commitment scale: Pre-design scale on employee's organizational commitment refers to the revised version of TCM Employee Commitment Survey of Meyer, Allen, and Smith (1993). After experts' discussion, four reverse-scored (negative) items are converted to positive items, three items are edited to make the meaning clearer and two new items are added. Hence, organizational commitment scale consisted of 20 items, including three components: affective commitment, continuance commitment, and normative commitment.

Job performance scale: The study has borrowed from previous studies of Nguyen and Nguyen (2012), Rego and Cunha (2008), and Staples, Hulland, and Higgins (1999) to design questionnaire on employee's job performance. Then, the study edits one item and adds three new items based on the experts' opinion. Finally, job performance is measured by seven items. Last but, not least, five-point Likert scale (1 $=$ Strongly disagree, $5=$ Strongly agree) is used to measure the response level.

\subsection{Data}

Respondents are employees from several companies across industries in Vietnam. The questionnaire is sent to respondents in two ways: face-to-face and via email. As a result, 901 responses are collected. After removing duplicate or inaccurate records, the official sample size is 848 , including 421 male and 427 female. The number of respondents with at least five years of working experience make up the largest group, with 439 respondents. Some $25.7 \%$ of respondents have working experience from one year to less than three years and $19.8 \%$ of respondents have working experience from three years to less than five years. Interviewees responded with a minimum value of 1 , and a maximum value of 5 . The average values of all items of psychological capital scale are greater than 3 show that respondents have a psychological capital level, which is above average. They also self-describe as employees working effectively. Especially, the result of descriptive statistic of organizational commitment shows that the level of overall commitment, affective commitment, continuance commitment and normative commitment is above average. The meaningfulness and the family role of the organization are the main causes of employee's affective commitment.
Interviewees feel they have a responsibility to work for the organization in a long term. They also do not assume that salary, benefits, and lack of alternative places are main costs, if leaving. What is more, commitment to this organization is their current desire and needs.

\section{Results}

\subsection{Cronbach's Alpha with Scales}

The study assesses the reliability of scales by Cronbach's Alpha. The final results are obtained such as:

Psychological capital scale: there are eight items eliminated: SE1, HO7, HO12, RE17, RE19, RE21, OP23, OP24, the overall Cronbach's alpha of each component is: 0.853 (Self-efficacy scale), 0.826 (Hope scale), 0.803 (Resilience scale) and 0.848 (Optimism scale).

Organizational commitment scale: six items (OC75, OC77, OC80, OC81, OC82, OC83) are removed in the first three assessments. The overall Cronbach's alpha of each component is: 0.928 (affective commitment), 0.802 (continuance commitment), 0.859 (normative commitment).

Job performance scale: The overall Cronbach's Alpha is 0.889 . This scale still comprises of seven observed variables.

\subsection{Exploratory Factor Analysis}

The study applies Exploratory Factor Analysis to each concept, followed the Principal Axis Factoring extraction method and the Promax rotation method. Results of exploratory factor analysis are obtained as follows:

Psychological capital scale: This analysis is performed in two times. In the first analysis, item HO8 and item HO9 are removed because of their non-convergence. The analysis is conducted again and its results are four factors extracted such as: optimism (factor 1, OP), self-efficacy (factor 2, SE), resiliency (factor 3, RE), and hope (factor $4, \mathrm{HO}$ ).

Organizational commitment scale: results are obtained, i.e. KMO value is 0.928 , Barlett test has statistical significance with sig. $=.000$, three factors extracted are: affective commitment (factor 1, OC_1), normative commitment (factor 2, OC 2), continuance commitment (factor 3, OC_3) with Eigenvalue value at the third factor is 1.081 and the total variance extracted is $70.526 \%$.

Job performance scale: the result shows that only 1 factor is extracted, including items: JP35, JP34, JP31, JP36, JP33, JP32, JP37, and KMO value is 0.882, Barlett test has statistical significance with sig. $=.000$.

Exploratory factor analysis is performed with overall scale including all items of psychological capital scale, organizational commitment scale, and job performance scale. In the first analysis, item OC85 is rejected because of nonconvergence. The results of the second analysis are obtained: 
KMO value is 0.936 , Barlett test has statistical significance with sig. $=.000$, Eigenvalue at the eighth factor is 1.012 and the total variance extracted at this factor is $64.703 \%$. The extraction with eight factors is appropriate since factor 3 , factor 4 , factor 5 and factor 6 represent four components of psychological capital, factor 2 is job performance and the remaining factors are components of organizational commitment. Detailed results of each factor are shown in Table 1.

\subsection{Confirmatory Factor Analysis}

Psychological capital and organizational commitment are second-order constructs. Therefore, the analysis of confirmatory factor is implemented. In the measurement model of psychological capital, low-latent constructs include optimism (OP), self-efficacy (SE), resilience (RE) and hope (HO), high-latent construct is psychological capital (PsyCap). The results of the analysis are obtained: Chisquare $/ \mathrm{df}=2.032$, GFI $=0.945, \mathrm{CFI}=0.955$ and $\mathrm{RMSEA}$ $=0.051$, indicating that the measurement model is built in accordance with the collected research data. The model is also concluded to be reliable and valid when $\mathrm{CR}=0.883$, $\mathrm{AVE}=0.655, \mathrm{MSV}=0.000$.

In the measurement model of psychological capital, low-latent constructs include affective commitment (OC_1), normative commitment ( $\mathrm{OC} \_2$ ), continuance commitment (OC_3), high-latent construct is organizational commitment (OC). The results show that this measurement model receives an acceptable fit to the collected data: Chi-square/df $=2.13$, $\mathrm{GFI}=0.960, \mathrm{CFI}=0.976$ and $\mathrm{RMSEA}=0.056$. The model is also concluded to be reliable and valid when $\mathrm{CR}=0.781$, $\mathrm{AVE}=0.570, \mathrm{MSV}=0.000$.

After EFA of overall scale, the study performs CFA for the model of three main constructs: psychological capital (PsyCap), organizational commitment (OC), and job performance (JP). The analytical results help to conclude that the model is consistent with the research data collected, and achieve reliability and validity: Chi-square/df $=2.984$, $\mathrm{GFI}=0.914, \mathrm{CFI}=0.943, \mathrm{RMSEA}=0.048$.

\subsection{Structural Equation Modeling Analysis}

Psychological capital has a statistically significant positive relationship with employee's organizational commitment at the 1\% significance level. The magnitude of this impact is 0.692 . It means that the more psychological capital level employee has, the more his organizational commitment is. Therefore, hypothesis $\mathrm{H}_{2}$ is supported and this result is similar to the findings of other scholars (Nolzen, 2018; Aminikhah et al., 2016; Kappagoda, Othman, Fithri, \& De Alwis, 2014; Newman et al., 2014; Rus \& Băban, 2013;
Avey, Reichard, Luthans, \& Mhatre, 2011; Luthans et al., 2008; Larson \& Luthans, 2006).

Psychological capital has also a high positive (0.739) impact on job performance. This impact is statistically significant at the $1 \%$ significance level. This result supports not only the $\mathrm{H}_{1}$ hypothesis proposed, but also the opinion of Luthans and Youssef (2004) assuming that psychological capital helps improve employee's job performance. This results are similar to the results of previous empirical studies (Dinh, Dong, \& Ha, 2014; Kappagoda et al., 2014; Wang, Sui, Luthans, Wang, \& Wu, 2014; Liu, 2013; Nguyen \& Nguyen, 2012).

In this study, the third direct effect of organizational commitment on job performance is positive. This impact is very weak - only 0.061 and it is a statistical significance at the $5 \%$ significance level. Nevertheless, hypothesis $\mathrm{H}_{3}$ is still accepted. This result is in contrast to the result of other studies (Rageb, Abd-El-Salam, El-Samadicy, \& Farid, 2013) but is the same as that of (Sawitri, Suswati, \& Huda, 2016; Fu \& Deshpande, 2014; Ahmad, Ahmad, \& Shah, 2010; Abualrub \& Al-Zaru, 2008; Chen, Silverthorne, \& Hung, 2006; Jaramillo, Mulki, \& Solomon, 2006).

This study does not only investigate the direct relationships between concepts, but also explore the indirect effect of psychological capital on employee's job performance through his organizational commitment. The magnitude of this impact is 0.0422 . Therefore, the total effect of psychological on job performance is 0.74322 . The appearance of organizational commitment as the mediator helps increase the impact of psychological capital on job performance. The hypothesis $\mathrm{H}_{4}$ is also accepted.

During working, employee has to do various assignments to complete the organization's operating goals. These assignments can either be easy to accomplish or challenging causing failure. Employee with low psychological capital is afraid of challenges and has tendency to likely receive easy tasks, whereas those with high psychological capital consider working obstacles and barriers as opportunities and motives to learn and develop themselves. Beside that, upon high psychological capital employees' opinion, difficulties that they may confront don't exist in long term and that can help build their strength to deal with future obstacles.

As a result, they possess positive senses, prefer difficult tasks and try to overcome troublesome things to achieve their working goals. They think that they themselves can handle it (Youssef \& Luthans, 2007). As such, employees have positive attitude towards their job and want to closely engage to the organization because the organizational commitment reflects psychological state connecting an individual with an organization in terms of organizational goals and values (Allen \& Meyer, 1990). And thanks to the organizational commitment, employees focus on completing organizational 
Table 1: The Pattern matrix of overall scale

\begin{tabular}{|c|c|c|c|c|c|c|c|c|}
\hline \multirow{2}{*}{ Items } & \multicolumn{8}{|c|}{ Factor } \\
\hline & 1 & 2 & 3 & 4 & 5 & 6 & 7 & 8 \\
\hline OC70 & 0.892 & & & & & & & \\
\hline OC72 & 0.864 & & & & & & & \\
\hline OC73 & 0.861 & & & & & & & \\
\hline OC71 & 0.857 & & & & & & & \\
\hline OC68 & 0.777 & & & & & & & \\
\hline OC74 & 0.758 & & & & & & & \\
\hline OC69 & 0.731 & & & & & & & \\
\hline JP35 & & 0.848 & & & & & & \\
\hline JP36 & & 0.790 & & & & & & \\
\hline JP34 & & 0.764 & & & & & & \\
\hline JP31 & & 0.735 & & & & & & \\
\hline JP33 & & 0.641 & & & & & & \\
\hline JP37 & & 0.589 & & & & & & \\
\hline JP32 & & 0.522 & & & & & & \\
\hline SE2 & & & 0.776 & & & & & \\
\hline SE5 & & & 0.740 & & & & & \\
\hline SE6 & & & 0.717 & & & & & \\
\hline SE4 & & & 0.665 & & & & & \\
\hline SE3 & & & 0.610 & & & & & \\
\hline OP25 & & & & 0.845 & & & & \\
\hline OP30 & & & & 0.700 & & & & \\
\hline OP29 & & & & 0.685 & & & & \\
\hline OP26 & & & & 0.666 & & & & \\
\hline OP28 & & & & 0.575 & & & & \\
\hline OP27 & & & & 0.492 & & & & \\
\hline $\mathrm{HO} 14$ & & & & & 0.812 & & & \\
\hline $\mathrm{HO} 13$ & & & & & 0.754 & & & \\
\hline HO11 & & & & & 0.580 & & & \\
\hline HO10 & & & & & 0.521 & & & \\
\hline RE16 & & & & & & 0.632 & & \\
\hline RE18 & & & & & & 0.590 & & \\
\hline RE15 & & & & & & 0.546 & & \\
\hline RE20 & & & & & & 0.448 & & \\
\hline RE22 & & & & & & 0.418 & & \\
\hline OC79 & & & & & & & 0.899 & \\
\hline OC76 & & & & & & & 0.604 & \\
\hline OC78 & & & & & & & 0.513 & \\
\hline OC84 & & & & & & & & 0.701 \\
\hline OC86 & & & & & & & & 0.631 \\
\hline OC87 & & & & & & & & 0.554 \\
\hline
\end{tabular}


working goals rather than any specific assignments (Hulin, 1991). The higher level of organizational commitment is, the more effort of assignment accomplishment is because they believe that their working achievement will contribute to that of the organization. Employees are assessed to be productive at work when their behaviors and actions go beyond organizational goals (Motowildo, Borman, \& Schmit, 1997). Therefore, it is able to say that employees who have their high commitment with their organization will create high performance (see Figure 2).

\section{Conclusions and Recommendations}

Psychological capital and organizational commitment, in this study, are used as a second-order construct. There are four components under psychological capital, including self-efficacy, hope, optimism and resiliency, whereas three components, comprising affective commitment, continuance commitment and normative commitment are under organizational commitment.

Officers who work for several companies across industries in many provinces and cities of Vietnam are selected to attend the survey. The research sample size is 848 , of which employees with at least five years of working experience accounts for $51.8 \%$, followed by $25.7 \%$ and $19.8 \%$ of employees working from one year to less than three years and from three years to less than five years, respectively. There was hardly any respondents who work less than one year. Two methods of surveying are face-toface and via email.

This study combines qualitative research method and quantitative research method. Quantitative research method is used to estimate the relationship between concepts while qualitative research method helps complete the scale of concepts and ensures the conformity with the specific research context.

The research results show that there is a positive impact of psychological capital on organizational commitment and job performance of employees, by which organizational commitment is also proven to have a positive influence on job performance. Moreover, organizational commitment also mediates the positive relationship between psychological capital and employee's performance. As a result, all hypotheses are accepted.

Manager must find the best way to improve job performance (Tran, Lee, Nguyen, \& Srisittiratkul, 2020). This study explores the impact of employee's psychological capital and organizational commitment to his job performance. On the basis of the results, managers are recommended to increase employees' job performance by raising their psychological capital and organizational commitment. It is necessary for managers to take into consideration psychological capital as a factor that helps improve both organizational commitment and job performance of employees. More suggestions for managers are to develop a questionnaire to measure psychological capital according to the organization's characteristics of employees, business industries, etc., and periodically evaluate and organize shortterm psychological training courses for employees. It is also advised to create a friendly working environment with many engagement activities and development programs for employee's organizational commitment. Apart from those, in order to enhance employee's job performance, two-ways internal communication activities should be promoted within the organization to incorporate employee's personal working goals and needs with their assigned works.

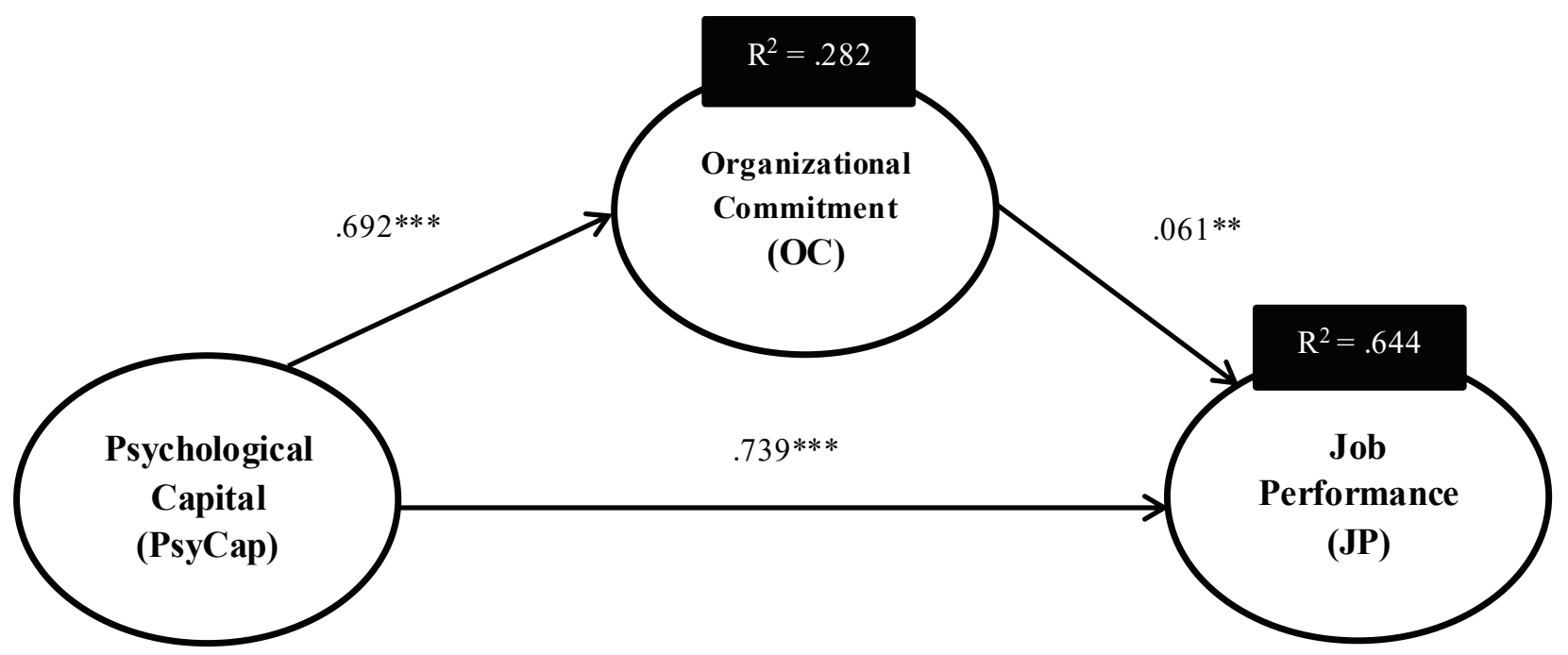

Figure 2: The result of the path model 


\section{References}

Abualrub, R. F., \& Al-Zaru, I. M. (2008). Job stress, recognition, job performance and intention to stay at work among Jordanian hospital nurses. Journal of Nursing Management, 16(3), 227236.

Ahmad, H., Ahmad, K., \& Shah, I. A. (2010). Relationship between job satisfaction, job performance attitude towards work and organizational commitment. European Journal of Social Sciences, 18(2), 257-267.

Allen, N. J., \& Meyer, J. P. (1990). The measurement and antecedents of affective, continuance and normative commitment to the organization. Journal of Occupational Psychology, 63(1), 1-18.

Aminikhah, H., Khaneghah, T. M., \& Naghdian, M. (2016). The relationship of psycological capital and job satisfaction with organizational commitment. International Journal of Information, Business and Management, 8(1), 153-171.

Avey, J. B., Luthans, F., \& Jensen, S. M. (2009). Psychological capital: A positive resource for combating employee stress and turnover. Human Resource Management, 48(5), 677-693.

Avey, J. B., Reichard, R. J., Luthans, F., \& Mhatre, K. H. (2011). Meta-analysis of the impact of positive psychological capital on employee attitudes, behaviors, and performance. Human Resource Development Quarterly, 22(2), 127-152.

Bandura, A. (1997). Self-efficacy: The exercise of control. New York, NY: W H Freeman/Times Books/ Henry Holt \& Co.

Bateman, T. S., \& Strasser, S. (1984). A longitudinal analysis of the antecedents of organizational commitment. Academy of Management Journal, 27(1), 95-112.

Campbell, J. P., McCloy, R. A., Oppler, S. H., \& Sager, C. E. (1993). A theory of performance. Personnel Selection in Organizations, 3570, 35-70.

Campbell, J. P., McHenry, J. J., \& Wise, L. L. (1990). Modeling job performance in a population of jobs. Personnel Psychology, $43(2), 313-575$.

Chen, J.-C., Silverthorne, C., \& Hung, J.-Y. (2006). Organization communication, job stress, organizational commitment, and job performance of accounting professionals in Taiwan and America. Leadership \& Organization Development Journal, 27(4), 242-249.

Corr, P. J., \& Gray, J. A. (1996). Attributional style as a personality factor in insurance sales performance in the UK. Journal of Occupational and Organizational Psychology, 69(1), 83-87.

Dinh, N. T., Dong, N. P., \& Ha, T. M. Q. (2014). Marketers' psychological capital and performance: the mediating role of quality of work life, job effort and job attractiveness. AsiaPacific Journal of Business Administration, 6(1), 36-48.

Farran, C., Herth, K., \& Popovich, J. (1995). Hope and hopelessness: critical clinical concepts: Thousand Oaks, CA: Sage.

Fu, W., \& Deshpande, S. P. (2014). The impact of caring climate, job satisfaction, and organizational commitment on job performance of employees in a China's insurance company. Journal of Business Ethics, 124(2), 339-349.
Hulin, C. (1991). Adaptation, persistence, and commitment in organizations. In M. D. Dunnette \& L. M. Hough (Eds.), Handbook of industrial and organizational psychology (pp. 445-505). Sunnyvale, CA: Consulting Psychologists Press.

Jaramillo, F., Mulki, J. P., \& Marshall, G. W. (2005). A meta-analysis of the relationship between organizational commitment and salesperson job performance: 25 years of research. Journal of Business Research, 58(6), 705-714.

Jaramillo, F., Mulki, J. P., \& Solomon, P. (2006). The role of ethical climate on salesperson's role stress, job attitudes, turnover intention, and job performance. Journal of Personal Selling \& Sales Management, 26(3), 271-282.

Judge, T. A., \& Kammeyer-Mueller, J. D. (2012). Job attitudes. Annual Review of Psychology, 63, 341-367.

Kappagoda, S., Othman, H., Fithri, Z., \& De Alwis, W. (2014). The impact of psychological capital on job performance in the banking sector in Sri Lanka. International Journal of Arts and Commerce, 3(5), 198-208.

Kluemper, D. H., Little, L. M., \& DeGroot, T. (2009). State or trait: effects of state optimism on job-related outcomes. Journal of Organizational Behavior, 30(2), 209-231.

Larson, M., \& Luthans, F. (2006). Potential added value of psychological capital in predicting work attitudes. Journal of Leadership \& Organizational studies, 13(1), 45-62.

Liu, Y. (2013). Mediating effect of positive psychological capital in Taiwan's life insurance industry. Social Behavior \& Personality: An International Journal, 41(1), 109-112. https:// doi.org/10.2224/sbp.2013.41.1.109.

Luthans, F., Avey, J. B., Avolio, B. J., \& Peterson, S. J. (2010). The development and resulting performance impact of positive psychological capital. Human Resource Development Quarterly, 21(1), 41-67.

Luthans, F., Avolio, B. J., Avey, J. B., \& Norman, S. M. (2007). Positive psychological capital: Measurement and relationship with performance and satisfaction. Personnel Psychology, 60(3), 541-572.

Luthans, F., Avolio, B. J., Walumbwa, F. O., \& Li, W. (2005). The psychological capital of Chinese workers: Exploring the relationship with performance. Management and Organization Review, 1(2), 249-271.

Luthans, F., Luthans, K. W., \& Luthans, B. C. (2004). Positive psychological capital: Beyond human and social capital. Business Horizons, 47(1), 45-50. DOI: 10.1016/j. bushor.2003.11.007

Luthans, F., Norman, S. M., Avolio, B. J., \& Avey, J. B. (2008). The mediating role of psychological capital in the supportive organizational climate - employee performance relationship. Journal of Organizational Behavior, 29(2), 219-238.

Luthans, F., \& Youssef, C. M. (2004). Human, social, and now positive psychological capital management: Investing in people for competitive advantage. Organizational Dynamics, 33(2), 143-160. DOI: 10.1016/j.orgdyn.2004.01.003

Luthans, F., Youssef, C. M., \& Avolio, B. J. (2015). Psychological capital and beyond. New York, NY: Oxford University Press. 
Luthans, K. W., \& Jensen, S. M. (2005). The linkage between psychological capital and commitment to organizational mission: A study of nurses. Journal of Nursing Administration, 35(6), 304-310.

Meyer, J. P., \& Allen, N. J. (1991). A three-component conceptualization of organizational commitment. Human Resource Management Review, 1(1), 61-89.

Meyer, J. P., Allen, N. J., \& Smith, C. A. (1993). Commitment to organizations and occupations: Extension and test of a threecomponent conceptualization. Journal of Applied Psychology, 78(4), 538-551. https://doi.org/10.1037/0021-9010.78.4.538

Meyer, J. P., Paunonen, S. V., Gellatly, I. R., Goffin, R. D., \& Jackson, D. N. (1989). Organizational commitment and job performance: It's the nature of the commitment that counts. Journal of Applied Psychology, 74(1), 152-156. https://doi. org/10.1037/0021-9010.74.1.152

Moorhead, G., \& Griffin, R. W. (2008). Organizational behavior managing people and organizations. New Delhi, India: Dreamtech Press.

Motowildo, S. J., Borman, W. C., \& Schmit, M. J. (1997). A theory of individual differences in task and contextual performance. Human Performance, 10(2), 71-83.

Murphy, K. R., \& Kroeker, L. P. (1988). Dimensions of job performance. DTIC Report. Retrieved August 25, 2018, from https://apps.dtic.mil/dtic/tr/fulltext/u2/a194951.pdf.

Newman, A., Ucbasaran, D., Zhu, F., \& Hirst, G. (2014). Psychological capital: A review and synthesis. Journal of Organizational Behavior, 35(S1), S120-S138.

Nguyen, T. D., \& Nguyen, T. T. (2012). Psychological capital, quality of work life, and quality of life of marketers: Evidence from Vietnam. Journal of Macromarketing, 32(1), 87-95.

Nguyen, T. H., \& Tu, V. B. (2020). Social Responsibility, Organizational Commitment, and Organizational Performance: Food Processing Enterprises in the Mekong River Delta. Journal of Asian Finance, Economics and Business, 7(2), 309316. https://doi.org/10.13106/jafeb.2020.vol7.no2.309

Nolzen, N. (2018). The concept of psychological capital: a comprehensive review. Management Review Quarterly, 68(3), 237-277.

Peterson, S. J., \& Byron, K. (2008). Exploring the role of hope in job performance: Results from four studies. Journal of Organizational Behavior, 29(6), 785-803. https://doi. org/10.1002/job.492

Rageb, M. A., Abd-El-Salam, E. M., El-Samadicy, A., \& Farid, S. (2013). Organizational commitment, job satisfaction and job performance as a mediator between role stressors and turnover intentions a study from an Egyptian cultural perspective.
International Journal of Business and Economic Development, 1(1), 34-54.

Rego, A., \& Cunha, M. P. (2008). Authentizotic climates and employee happiness: Pathways to individual performance? Journal of Business Research, 61(7), 739-752.

Riketta, M. (2002). Attitudinal organizational commitment and job performance: a meta-analysis. Journal of Organizational Behavior, 23(3), 257-266. https://doi.org/10.1002/job.141

Rus, C. L., \& Băban, A. (2013). Correlates of positive psychological capital: A synthesis of the empirical research published between January 2000 and January 2010. Cognition, Brain, Behavior, An Interdisciplinary Journal, 17(2), 109-133.

Sawitri, D., Suswati, E., \& Huda, K. (2016). The impact of job satisfaction, organizational commitment, organization citizenship behavior (OCB) on employees' performance. International Journal of Organizational Innovation, 9(2), 2445.

Shore, L. M., \& Martin, H. J. (1989). Job satisfaction and organizational commitment in relation to work performance and turnover intentions. Human Relations, 42(7), 625-638.

Staples, D. S., Hulland, J. S., \& Higgins, C. A. (1999). A selfefficacy theory explanation for the management of remote workers in virtual organizations. Organization Science, 10(6), 758-776.

Tran, D. T., Lee, L. Y., Nguyen, P. T., \& Srisittiratkul, W. (2020). How Leader Characteristics and Leader Member Exchange Lead to Social Capital and Job Performance. Journal of Asian Finance, Economics and Business, 7(1), 269-278. https://doi. org/10.13106/jafeb.2020.vol7.no1.269

Wang, H., Sui, Y., Luthans, F., Wang, D., \& Wu, Y. (2014). Impact of authentic leadership on performance: Role of followers' positive psychological capital and relational processes. Journal of Organizational Behavior, 35(1), 5-21.

Wright, T. A., \& Bonett, D. G. (2002). The moderating effects of employee tenure on the relation between organizational commitment and job performance: A meta-analysis. Journal of Applied Psychology, 87(6), 1183-1190. DOI: 10.1037/00219010.87.6.1183

Yang, H. C., \& Kim, Y. E. (2018). The Effects of Corporate Social Responsibility on Job Performance: Moderating Effects of Authentic Leadership and Meaningfulness of Work. Journal of Asian Finance, Economics and Business, 5(3), 121-132. http:// doi.org/10.13106/jafeb.2018.vol5.no3.121

Youssef, C. M., \& Luthans, F. (2007). Positive organizational behavior in the workplace: The impact of hope, optimism, and resilience. Journal of Management, 33(5), 774-800. 
